\title{
PENGARUH KUALITAS SISTEM PELAYANAN JASA TERHADAP PELANGGAN Felix Semaun
}

\author{
Fakultas Ilmu Sosial Politik Universitas Kapuas
}

\author{
Email: felix.unka@gmail.com \\ Universitas Kapuas Sintang, Jln. Y.C.Oevang Oeray No.92 Sintang, Kalimantan Barat
}

\begin{abstract}
Abstrak, Seiring dengan perkembangan zaman yang disertai dengan kemajuan teknologi saat ini mengakibatkan kebutuhan hidup masyarakat baik perseorangan maupun perusahaan semakin meningkat. Meningkatnya tingkat perpindahan atau pengiriman barang dari suatu wilayah ke wilayah lainnya ini memberikan kesempatan besar untuk berkembangnya perusahaan-perusahaan logistik terutama perusahaan jasa yang bergerak di bidang pengiriman barang maupun dokumen.PT.Pos IndonesiamerupakanBUMNyang bergerakdalamkegiatan pelayananlalu lintasinformasi,uangdanbarang
\end{abstract}

Kata kunci : Pengiriman, Pelayanan

Seiringdengan perkembangan zaman yang disertai dengan kemajuan teknologi saat ini mengakibatkan kebutuhan hidup masyarakat baik perseorangan maupun perusahaan semakin meningkat. Dengan semakin meningkatnya kebutuhan masyarakat mengakibatkan adanya perpindahan barang diberbagai tempat. Hal ini terjadi karena adanya perbedaan geografis antara suatu wilayah dengan wilayah lainnya. Meningkatnya tingkat perpindahan atau pengiriman barang dari suatu wilayah ke wilayah lainnya ini memberikan kesempatan besar untuk berkembangnya perusahaan-perusahaan logistik terutama perusahaan jasa yang bergerak di bidang pengiriman barang maupun dokumen.

PT. Pos Indonesia merupakan BUMN yang bergerak dalam kegiatan pelayanan lalu lintasinformasi, uang dan barang. Pengiriman barang belum dapat tergantikan dengan teknologi manapun dengan piranti apa pun. Salah satu diferensiansi produk yang ditawarkan oleh PT. Pos Indonesia (Persero) adalah jasa layanan pengiriman paket. Jasa pengiriman paket memiliki prospek yang sangat baik tetapi kenyataannya sebagian besar pangsa pasar jasa pengiriman paket dikuasai oleh perusahaan jasa titipan swasta, mendorong motivasi, persepsi, dan sikap konsumen untuk dapat menghasilkan produk/jasa yang memiliki daya saing tinggi dalam usaha memenangkan pangsapasar. Pos Indonesia dewasa ini melakukan inovasi untuk memenuhi kebutuhan pelanggan.

Salah satu inovasi yang dilakukan PT. Pos Indonesia adalah layanan pos yang menggunakan jaringan internet atau online. Pos Indonesia mempunyai jaringan yang sangat luas yaitu kurang lebih 4.800 kantor pos di Indonesia. Sedangkan jumlah titik layanannya (poin of sales) mencapai 58.700 titik dalam bentuk kantor pos sendiri, agensi/agen pos, pos keliling desa/kota, pos sekolah, postmall, dan lain-lain (www.posindonesia.co.id, 2016). Dengan jaringan yang sangat luas ini, kantor pos merupakan media yang sangat strategis menjual dan atau mendistribusikan barang atau jasa. Pos Indonesia telah memiliki jaringan yang dedicated, sistem distribusi, track\&trace, layanan prima, kecepatan dan ketepatan serta harga yang kompetitif.Usaha dalam bidang jasa seperti PT. Pos Indonesia merupakan usaha yang berdasarkan pada azas kepercayaan mengutamakan atas kualitas pelayanan (service quality). Kualitas pelayanan ini menjadi faktor penting dalam menentukan keberhasilan suatu perusahaan. Fenomena ini juga hampir terjadi di seluruh perusahaan yang bergerak dibidang jasa lainya, dimana pelanggan juga mengingikan adanya peningkatan kualitas pelayanan seca terus-menerus ketika menggunakan jasa yang ada disuatu perusahaan. Menurut Pasuraman, Zeithml, dan Berry (Tjiptono dan Chandra 2016:13) terdapat lima dimensi kualitas pelayanan yang diurutkan berdasarkan tingkat kepentingan relatifnya, yaitu : realibilitas (reliability), daya tanggap (responsiveness), jaminan (assurance), empati (emphaty) dan bukti fisik (tangibles).

Kantor Pos Indonesia cabang Pandan Sintang adalah cabang kantor pos yang berada di desa Merarai Satu, kecamatan Sungai Tebelian, Kabupaten Sintang. Kantor pos ini telah menggunakan sistem online yang melayani jasa pengiriman surat, paket, dan jasa keuangan seperti wesel, pospay dan lain-lain. Semakin banyaknya produk jasa yang ditawarkan, seharusnya semakin meningkatnya kualitas pelayanan sehingga 
kebutuhan pelanggan dapat terpenuhi. Adapun beberapa masalah atau kelemahan yang terdapat pada PT. Pos Indonesia cabang Pandan Sintang yang meliputi beberapa dimensi kualitas pelayanan seperti: dari segi bukti fisik (tangibles) area parkir yang belum tertata sehingga terkesan tidak teratur, kurangnya tempat tunggu pelanggan dan tidak terdapatnya pendingin ruangan (air conditioner), dari segi daya tanggap (responsiveness) hanya terdapat satu kasir sehingga pelanggan harus lama mengantri saat terjadinya lonjakan pelanggan, dan dari segi reliabilitas (realibility) sering terjadinya gangguan jaringan sehingga menimbulkan ketidak nyamanan pelanggan saat akan melakukan transaksi. Berdasarkan uraian latar belakang maka penulis tertarik untuk meneliti lebih jauh pengaruh kualitas pelayanan jasa terhadap kepuasan pelanggan, dengan mengangkat judul "Pengaruh Kualitas Pelayanan Jasa Terhadap Kepuasan Pelanggan Pada PT. Pos Indonesia Cabang Sintang".penelitian ini memfokuskan pada: Adakah terdapat pengaruh kualitas pelayanan jasa tehadap kepuasan pelanggan pada PT. Pos Indonesia cabang Pandan Sintang?Berapa besarkah pengaruh kualitas pelayanan jasa tehadap kepuasan pelanggan pada PT. Pos Indonesia cabang Pandan Sintang? Tujuan umum dari penelitian ini adalah "Mengetahui pengaruh kualitas pelayanan jasa terhadap kepuasan pelanggan pada PT. Pos Indonesia cabang Pandan Sintang." Adapun yang menjadi tujuan khusus dalam penelitian ini adalah: 1). Mengetahui apakah terdapat pengaruh kualitas pelayanan jasa terhadap kepuasan pelanggan pada PT. Pos Indonesia cabang Pandan Sintang. 2). Mengetahui seberapa besar pengaruh kualitas pelayanan jasa terhadap kepuasan pelanggan pada PT. Pos Indonesia cabang Pandan Sintang.Adapun kegunaan yang diharapkan dari penelitian adalah sebagai berikut:Secara teoritis, diharapkan dari hasil penelitian ini menjadi salah satu karya ilmiah yang dapat memberi kontribusi dalam pengembangan ilmu Administrasi Niaga pada umumnya, dan khususnya untuk kajian kebijakan dan strategi pemasaran.Secara Praktis, untuk memberikan masukan bagi pihak perusahaan dalam memecahkan masalah yang dihadapi khususnya masalah yang menyangkut tentang pelayanan dalam rangka meningkatkan kepuasan pelanggan.

\section{Metode Penelitian}

\section{Rancangan Penelitian}

Pendekatan yang digunakan dalam penelitian ini adalah pendekatan kuantitatif. Penelitian kuantitatif menggunakan instrumen (alat pengumpul data) yang menghasilkan data numerikal (angka). Analisis data dilakukan menggunakan teknik statistik untuk mereduksi dan mengelompokan data, menentukan hubungan serta mengidentifikasi perbedaan antar kelompok data. Sedangkan menurut jenisnya, penelitian ini termasuk penelitian eksplanatoris, penelitian eksplanatoris adalah penelitian bertujuan untuk menguji suatu teori atau hipotesis guna memperkuat atau bahkan menolak teori atau hipotesis hasil penelitian yang sudah ada sebelumnya.

\section{Objek Penelitian}

Objek penelitian merupakan suatu hal yang berkenaan dengan tempat dimana penelitian di lakukan atau tempat terjadinya masalah yang diteliti. Dalam penyusunan penelitian ini, maka penulis melakukan penelitian di PT. Pos Indonesia cabang Pandan sintang. Alasan peneliti memilih objek tersebut adalah dengan pertimbangan bahwa peneliti berdomisili di kecamatan yang sama sehingga mempermudah memperoleh data serta waktu, tenaga, dan biaya yang di digunakan seefisien mungkin.

\section{Populasi dan Sampel}

Populasi

Menurut Sugiyono (2015:80) bahwa "Populasi adalah wilayah generalisasi yang terdiri atas: obyek atau subyek yang mempunyai kualitas atau karakteristik tertentu yang ditetapkan oleh peneliti untuk dipelajari dan di tarik kesimpulanya". Populasi dalam penelitian ini yaitu pengguna layanan jasa PT. Pos Indonesia cabang Sintang Pandan.

\section{Sampel}

Menurut Sugiyono (2015:81) bahwa "sampel adalah bagian dari jumlah dan karakteristik yang dimiliki oleh populasi tersebut". Menurut Mao Purba (Ghazali, 2010:11) dalam menentukan besarnya sampel, maka digunakan rumus sebagai berikut:

$$
n=\frac{Z^{2}}{4(M \circ e)^{2}}
$$

Dimana:

$\mathrm{Z}=$ Tingkat keyakinan yang di butuhkan dalam penelitian sampel.

Moe $=$ Margin of error, atau tingkat tingkat kesalahan maksimum yang dapat di tolerir

$\mathrm{n}=$ Besarnya sampel 
Alasan menggunakan rumus tersebut adalah karena jumlah populasi yang tidak di ketahui secara pasti. Tingkat yang digunakan adalah 95 persen atau $Z=1,96$ dan Moe $=10$ persen $(0,1)$. Maka jumlah sampel penelitian ini adalah:

$$
\begin{aligned}
& n=\frac{(1,96)^{2}}{4(0,1)^{2}} \\
& n=96,04
\end{aligned}
$$

Berdasarkan perhitungan yang di peroleh di atas, maka jumlah sampel yang di teliti adalah 96,04 . Untuk memudahkan penelitian maka peneliti mengambil sampel sebesar 100 responden.

Teknik sampling yang di gunakan dalam penelitian ini adalah teknik sampling aksidental. Menurut Sugiyono (2006:73) aksidental sampling adalah "teknik penentuan sampel secara kebetulan bertemu dengan peneliti dapat digunakan sebagai sampel, bila dipandang orang yang kebetulan ditemui cocok dengan sumber data."

\section{Variabel Penelitian}

Menurut Sugiyono (2015:38) bahwa "variabel penelitian adalah suatu atribut atau sifat atau nilai dari orang, obyek atau kegiatan yang mempunyai variasi tertentu yang ditetapkan oleh peneliti untuk dipelajari lalu ditarik kesimpulannya."

\section{1) Variabel bebas (Independen)}

Menurut Sugiyono (2015:39) variabel bebas adalah "variabel yang mempengaruhi atau yang menjadi sebab perubahannya atau timbunya variabel terikat (dependen). Variabel bebas (independen) dalam penelitian ini adalah kualitas pelayanan jasa (X). Dalam penelitian ini, peneliti menggabung kelima dimensi kualitas pelayanan jasa yang yang yang disusun sesuai urutan tingkat kepentingan relatifnya meliputi: realibilitas (realibility), daya tanggap (responsiveness), jaminan (assurance) empati (emphaty), dan bukti fisik (tangibles) ( Tjiptono dan Chandra 2016:137).

(1). Realibilitas (reliability), berkaitan dengan kemampuan perusahaan untuk memberikan layanan yang akurat sejak pertama kali tanpa membuat kesalahan apapun dan menyampaikan jasanya sesuai waktu yang di sepakati.

(2). Daya tanggap (responsiveness) berkenaan dengan kesediaan dan kemampuan para karyawan untuk membantu para pelanggan dan merespon permintaan mereka, serta menginformasikan kapan saja akan di berikan dan kemudian memberikan jasa secara tepat.
(3). Jaminan (assurance), yaitu perilaku para karyawan mampu menumbuhkan kepercayaan pelanggan terhadap perusahaan dan perusahaan bisa menciptakan rasa aman bagi para pelanggannya. Jaminan berarti juga para karyawan selalu bersikap sopan dan menguasai pengetahuan dan ketrampilan yang dibutuhkan untuk menangani setiap pertanyaan atau masalah pelanggan.

(4). Empati (emphaty), berarti bahwa perusahaan memahami masalah para pelanggannya dan bertindak demi kepentingan pelanggan, serta memberikan perhatian personal kepada para pelanggan dan memiliki jam operasi yang nyaman.

(5). Bukti fisik (tangibles), berkenaan dengan daya tarik fisik, perlengkapan, dan material yang di gunakan perusahaan serta penampilan karyawan.

\section{2) Variabel terikat (dependen)}

Menurut Sugiyono (2015:39) bahwa "variabel terikat (dependen) merupakan variabel yang dipengaruhi atau yang menjadi akibat, karena adanya variabel bebes (independen). Variabel terikat (dependen) dalam penelitian ini adalah kepuasan pelanggan (Y). dalam penelitian ini, peneliti menggabungkan aspek kepuasan pelanggan yang merupakan suatu tingkat dimana kebutuhan, keinginan dan harapan pelanggan dapat terpenuhi yang akan mengakibatkan terjadinya pembelian ulang atau kesetiaan yang berlanjut (Musanto 2004:125).

\section{Instrumen Penelitian}

Menurut Sugiyono (2015:102) menyatakan bahwa "instrumen penelitian adalah suatu alat yang digunakan untuk mengukur fenomena alam maupun sosial yang diamati." Instrumen dalam penelitian ini adalah berupa lembar kuesioner. Kuesioner merupakan teknik pengumpulan data yang dengan cara memberi seperangkat pertanyaan atau pernyataan tertulis kepada responden untuk dijawab. Pengisian kuesioner kualitas pelayanan jasa dan kepuasan pelanggan diukur dengan menggunakan skala likert yang terdiri atas: sangat setuju, setuju, cukup setuju, tidak setuju, sangat tidak setuju. Kelima penilaian tersebut diberi skor sebagai berikut:

Tabel 1. skor atas jawaban kuesioner kualitas pelayanan jasa dan kepuasan pelanggan 


\begin{tabular}{|c|c|c|}
\hline No & Jenis Jawaban & Skor \\
\hline 1 & Sangat setuju & 5 \\
\hline 2 & Setuju & 4 \\
\hline 3 & Cukup setuju & 3 \\
\hline 4 & Tidak setuju & 2 \\
\hline 5 & Sangat tidak setuju & 1 \\
\hline
\end{tabular}

Sumber: Riduwan dan Sunarto (2013:21)

Pengujian dan penganalisaan terhadap instrumen yang akan digunakan dengan langkahlangkah sebagai berikut:

1) Uji validitas instrumen

"Validitas adalah suatu ukuran yang menunjukan tingkat kevalidan atau kesahihan suatu instrumen. Suatu instrumen dikatakan valid apabila mampu mengukur apa yang hendak diukur", (Riduwan dan Sunarto, 2009:348). Menurut Arikunto (2010:211) "validitas adalah suatu ukuran yang menunjukan tingkat-tingkat kevalidan atau kesahihan sesuatu instrumen". Sugiyono (2004) mengemukakan bahwa: "alat ukur yang digunakan adalah dengan menggunakan rumus teknik korelasi Product Moment, guna menghitung korelasi antar masingmasing pernyataan dengan skor total".

Rumus Korelasi Product Moment adalah sebagai berikut:

$$
\begin{aligned}
& r=\frac{n \sum x \sum y}{\sqrt{\left\{n \sum x^{2}-(x)^{2}\right\}\left\{n \sum y^{2}-(y)^{2}\right\}}} \\
& \mathrm{r}=\text { koefisien korelasi } \\
& \mathrm{n}=\text { jumlah observasi atau responden } \\
& \mathrm{x}=\text { skor pertanyaan } \\
& \mathrm{y}=\text { skor total }
\end{aligned}
$$

Menurut Sugiyono (2015:126) bahwa "bila korelasi tiap faktor tersebut positif dan besarnya 0,3 ke atas maka faktor tersebut merupakan construct yang kuat." Pengujian validitas angket dalam penelitian ini digunakan program SPSS 21 for Windows.

\section{2) Uji reliabilitas instrumen}

Menurut Sugiyono (2013:121) "instrumen yang realibel adalah instrumen yang bila digunakan beberapa kali untuk mengukur objek yang sama". Menurut Arikunto (2010:221) "instrumen yang baik tidak bersifat tendensius mengarahkan responden untuk memilih jawaban-jawaban tertentu." Realibilitas instrumen merupakan syarat untuk pengujian validitas instrumen.
Menurut Sugiyono (2013:130) bahwa "pengujian reliabilitas dapat dilakukan secara eksternal maupun internal, secara eksternal pengujian dapat dilakukan test-retest (stability), equivalen, dan gabungan keduanya. Secara internal dapat diuji dengan menganalisis konsistensi butirbutir yang ada pada instrumen dengan teknik tertentu. Husein (Hermansyah, 2014:222) mengemukakan bahwa "untuk mencari realibilitas instrumen yang skornya bukan 0-1, tetap merupakan rentang antara beberapa nilai, misalnya 00-10 atau 0-100 atau dalam bentuk skala 1-3, 15, atau 1-7 dan seterusnya dapat menggunakan rumus Cronbach's Alpha berikut:"

$$
\begin{aligned}
r_{11} & =\left(\frac{k}{k-1}\right)\left(1-\frac{\sum \sigma_{b}^{2}}{\sigma_{t}^{2}}\right) \\
r_{11} & =\text { reliabilitas instrumen } \\
\mathrm{k} & =\text { banyak butir pertanyaan } \\
\bigodot_{\sigma_{b}^{2}} & =\text { varians total } \\
\sigma_{t}^{2} & =\text { jumlah varians butir }
\end{aligned}
$$

Untuk mencari varians, di gunakan rumus sebagai berikut:

$\sigma=\frac{\sum X^{2} \frac{\sum X^{2}}{n}}{n}$

Dimana:

$$
\begin{array}{ll}
n & =\text { jumlah sampel } \\
\mathrm{X} & =\text { nilai skor yang dipilih }
\end{array}
$$

Menurut Nasution dan Usman (Hermansyah 2006) bahwa "jika koefisien reliabilitas mendekati 1 sangat baik, jika berada di atas 0,8 baik, tetapi bila di bawah nilai 0,6 tidak baik." Pengujian reliabilitas angket dalam penelitian ini digunakan program SPSS 21 for Windows.

\section{Teknik Pengumpulan Data}

Teknik pengumpulan data yang peneliti gunakan dalam penelitian ini adalah:

1) Kuesioner (angket)

Sugiyono (2015:142) mengemukakan bahwa "kuesioner merupakan teknik pengumpulan data yang dilakukan dengan cara memberi seperangkat pertanyaan atau pernyataaan tertulis kepada responden untuk dijawab". Kuesioner merupakan teknik pengumpulan data yang efisien bila peneliti tahu dengan pasti variabel yang akan di ukur dan tahu apa yang diharapkan responden. 


\section{2) Dokumentasi}

Menurut Sugiyono (2015:140) bahwa "dokumen merupakan catatan peristiwa yang telah berlalu. Dokumen bisa berbentuk tulisan, gambar, atau karya-karya monumental dari seseorang." Dokumen yang berbentuk tulisan misalnya catatan harian, sejarah kehidupan, ceritera, biografi, peraturan, kebijakan. Dokumen yang berbentuk gambar misalnya foto, gambar hidup, sketsa dan lain-lain.

\section{Teknik Analisis Data}

Dalam penelitian ini, peneliti menggunakan statistik non parametris. Digunakannya statistik non parametris karena data yang dianalisis merupakan data ordinal.

\section{Analisis Regresi Sederhana}

Menurut Riduwan dan Sunarto (2013:96) bahwa "kegunaan regresi dalam penelitian salah satunya adalah untuk meramalkan atau memprediksi variabel terikat (Y) apabila variabel bebas (X) diketahui." Adapun rumus regresi sederhana adalah sebagai berikut:

$$
\hat{Y}=a-b X
$$

\section{Dimana:}

$$
\begin{aligned}
& a=\frac{\left(\sum X\right)\left(\sum X^{2}\right)-\left(\sum X\right)\left(\sum X Y\right)}{n \sum X Y-\left(\sum \bar{X}\right)\left(\sum Y\right)^{2}} \\
& b=\frac{n X^{2}-\left(\sum X\right)^{2}}{n X^{2}}
\end{aligned}
$$

$\mathrm{v}=$ subjek variabel terikat yang diproyeksi

$\mathrm{X} \quad=$ variabel bebas yang memiliki nilai tertentu untuk diprediksikan

Dalam analisis regresi sederhana ini, peneliti menggunakan program SPSS 21 For Window.

\section{Analisis Korelasi Spearman Rank}

Menurut Sugiyono (2015:153) bahwa "untuk mengetahui tingkat hubungan (korelasi) bila datanya berbentuk ordinal maka digunakan teknik statistik Korelasi Spearman Rank". Dengan rumus sebagai berikut:

$$
r_{s}(r h o)=1-\frac{6 \sum d^{2}}{n\left(n^{2}-1\right)}
$$

$r_{s} \quad=$ Nilai Korelasi Spearman Rank

$d^{2} \quad=$ Selisih setiap pasangan rank

$n \quad=$ Jumlah responden

Tabel 2. Tabel untuk memberikan interpretasi koefisien korelasi

\begin{tabular}{|c|c|}
\hline Interval Koefisien & Tingkat Hubungan \\
\hline $0,00-0,199$ & Sangat rendah \\
$0,20-0,399$ & Rendah \\
$0,40-0,599$ & Sedang \\
$0,60-0,799$ & Kuat \\
$0,80-1,000$ & Sangat kuat \\
\hline
\end{tabular}

Sumber : Sugiyono (2015:184)
Dalam analisis Korelasi Spearman Rank ini, Peneliti menggunakan program SPSS 21 For Window.

\section{Uji hipotesis}

Untuk menguji hipotesis pengaruh kualitas pelayanan terhadap kepuasan pelanggan, maka peneliti menggunakan rumus sebagai berikut:

$$
t=r \sqrt{\frac{n-2}{1-r^{2}}}
$$

Dengan derajat kebebasanya $n-2$

Untuk mengetahui ditolak atau tidaknya hipotesis, maka dapat dinyatakan dalam kriteria berikut:

Bila t hitung $<\mathrm{t}$ tabel maka Ho diterima dan $\mathrm{Ha}$ ditolak.

Bila $\mathrm{t}$ hitung $>\mathrm{t}$ tabel maka Ho ditolak dan $\mathrm{Ha}$ diterima.

\section{Uji Koefisien Determinasi $\left(\mathrm{R}^{2}\right)$}

Untuk mengetahui arah dan pengaruh antara variabel bebas $(\mathrm{X})$ dan variabel terikat $(\mathrm{Y})$ digunakan koefisien determinasi $\left(\mathrm{R}^{2}\right)$. Besarnya koefisien adalah 0 sampai dengan 1 . Jika koefisien determinasi 0 berarti tidak ada pengaruh antara variabel bebas dan variabel terikat, apabila koefisien determinasi semakin mendekati 1 maka pengaruh tersebut positif dan kuat. Koefisien determinasi $\left(\mathrm{R}^{2}\right)$ digunakan untuk mengetahui tingkat yang paling baik antara dua variabel atau digunakan untuk mengukur besarnya konstribusi dari variabel $X$ terhadap variasi naik turunnya variabel $\mathrm{Y}$ yang biasnya dinyatakan dalam persentase. Adapun rumus Koefisien determinasi $\left(\mathrm{R}^{2}\right)$ adalah sebagai berikut:

$$
R^{2}=r^{2} \times 100 \%
$$

\section{Hasil dan Pembahasan}

\section{a. Uji Validitas}

Validitas adalah suatu ukuran yang menunjukan tingkat kevalidan atau kesahihan suatu instrumen. Suatu instrumen dikatakan valid apabila mampu mengukur apa yang hendak diukur. alat ukur yang digunakan adalah dengan menggunakan rumus teknik korelasi Product Moment, guna menghitung korelasi antar masing-masing pernyataan dengan skor total. Adapun hasil uji validitas yang diolah menggunakan SPSS 21 For Window adalah sebagai berikut: 
Tabel 3 Hasil Uji Validitas Instrumen Kualitas Pelayanan Jasa (X)

\begin{tabular}{|c|c|c|c|}
\hline Item & $\begin{array}{c}\text { Corrected Item - Total } \\
\text { Correlation }\end{array}$ & r kritis & Keterangan \\
\hline P1 & 0,37 & 0,3 & Valid \\
\hline P2 & 0,51 & 0,3 & Valid \\
\hline P3 & 0,414 & 0,3 & Valid \\
\hline P4 & 0,463 & 0,3 & Tidak Valid \\
\hline P5 & 0,136 & 0,3 & Valid \\
\hline P6 & 0,711 & 0,3 & Valid \\
\hline P7 & 0,352 & 0,3 & Valid \\
\hline P8 & 0,555 & 0,3 & Valid \\
\hline P9 & 0,461 & 0,3 & Valid \\
\hline P10 & 0,368 & 0,3 & Valid \\
\hline P11 & 0,575 & 0,3 & Valid \\
\hline P12 & 0,642 & 0,3 & Valid \\
\hline P13 & 0,396 & 0,3 & Valid \\
\hline P14 & 0,595 & 0,3 & 0,3 \\
\hline P15 & 0,515 & & \\
\hline
\end{tabular}

Sumber: data primer yang diolah dengan program SPPS 21 For Window

Dari Tabel 3. Hasil Uji Validitas Instrumen Kualitas Pelayanan Jasa (X) dapat di simpulkan bahwa instrumen pada variabel Kualitas Pelayanan Jasa $(\mathrm{X})$ yang peneliti ajukan dari 15 pertanyaan terdapat 1 pertanyaan yang tidak valid yaitu pertanyaan nomor kelima (P5) dimana nilai $r$ hitung $0,136>0,3$. Dalam uji validitas, peneliti menghapus butir instrumen yang tidak valid.

Tabel 4. Hasil Uji Validitas Instrumen Kepuasan Pelanggan (Y)

\begin{tabular}{|c|c|c|c|}
\hline Item & $\begin{array}{c}\text { Corrected Item - Total } \\
\text { Correlation }\end{array}$ & r kritis & Keterangan \\
\hline P1 & 0,515 & 0,3 & Valid \\
\hline P2 & 0,39 & 0,3 & Valid \\
\hline P3 & 0,508 & 0,3 & Valid \\
\hline P4 & 0,63 & 0,3 & Valid \\
\hline P5 & 0,608 & 0,3 & Valid \\
\hline & 0,505 & 0,3 & Valid \\
\hline
\end{tabular}

Sumber: data primer yang diolah dengan program SPPS 21 For Window

Dari Tabel 4 Hasil Uji Validitas Instrumen Kepuasan Pelanggan (Y) di atas dapat disimpulkan bahwa instrumen pada variabel Kepuasan Pelanggan (Y) yang peneliti ajukan semuanya valid, dimana nilai $r$ hitung pertanyaan satu sampai lima lebih besar dari pada $r$ kritis sehingga kelima pertanyaan kepuasan pelanggan (Y) layak digunakan.

\section{b. Uji Relibilitas}

Reliabilitas merupakan indeks yang menunjukan sejauh mana suatu alat ukur dapat dipercaya atau dapat diandalkan. Pengujian reliabilitas dalam penelitian ini adalah menggunakan rumus Cronbach alpha karena instrumen penelitian ini angket dan skala bertingkat. Ada pun hasil uji reliabilitas yang diolah menggunakan program SPSS 21 For Window adalah sebagai berikut: 
Tabel 5. Hasil Uji Reliabilitas

\begin{tabular}{c|c|c|c|}
\hline Variabel & $\begin{array}{c}\text { Cronbach' } \\
\text { s Alpha }\end{array}$ & r kritis & Keterangan \\
\hline $\begin{array}{c}\text { Variabel X } \\
\text { (Kualitas Pelayanan Jasa) }\end{array}$ & 0,836 & 0,6 & Realiabel \\
\hline $\begin{array}{c}\text { Variabel Y } \\
\text { (Kepuasan Pelanggan) }\end{array}$ & 0,694 & 0,6 & Realiabel \\
\hline
\end{tabular}

Sumber: data primer yang diolah dengan program SPPS 21 For Window

Dari tabel Tabel 4.7. Hasil Uji Reliabilitas dapat disimpulkan bahwa semua variabel Kualitas Pelayanan Jasa (X) dan Kepuasan Pelanggan (Y) dapat dikatakan reliabel, dikarenakan nilai Cronbach'h Alpha lebih besar dari r kritis. Dimana nilai Cronbach'h Alpha Kualitas Pelayanan Jasa (X) sebesar 0,836 > 0,6, maka dapat dikatakan realibel. Begitu pula nilai Cronbach'h Alpha variabel Kepuasan Pelanggan (Y) sebesar 0,694 maka variabel Kepuasan Pelanggan 0,694 maka variabel Kepuasan Pelanggan (Y) ini pun dapat dikatakan reliabel.

c. Analisis Deskripsi Kualitas Pelayanan jasa (X) dan Kepuasan Pelanggan (Y)

Tabel 6. Hasil Kuesioner Kualitas Pelayanan Jasa (X)
Untuk menunjang kepuasan pelanggan, maka salah satu upaya yang dilakukan oleh setiap perusahaan khususnya perusahaan yang bergerak di bidang jasa sangat perlu memberikan penerapan kualitas pelayanan, sebab dengan adanya peningkatan kualitas pelayanan, maka akan dapat memengaruhi kepuasan pelanggan. Dalam meningkatkan kualitas pelayanan pelanggan pada PT. Pos Indonesia Cabang Pandan Sintang, maka perlu dilakukan analisis mengenai kualitas pelayanan. Hal ini bertujuan untuk dapat melihat sebagian besar pengaruh kualitas pelayanan yang diberikan oleh PT. PosIndonesiaCabang Pandan Sintang

\begin{tabular}{|c|c|c|c|c|c|c|}
\hline \multirow{2}{*}{ No } & \multirow{2}{*}{ Item pertanyaan } & \multicolumn{2}{|l|}{ SS } & \multicolumn{2}{|l|}{$\mathbf{S}$} & \\
\hline & & $\mathbf{F}$ & $\%$ & $\mathbf{F}$ & $\%$ & $\mathbf{F}$ \\
\hline 1 & $\begin{array}{l}\text { Memberikan } \quad \text { pelayanan } \\
\text { sesuai janji }\end{array}$ & 38 & 38 & 49 & 49 & 11 \\
\hline 2 & $\begin{array}{l}\text { Melakukan pelayanan yang } \\
\text { tepat dan akurat }\end{array}$ & 37 & 37 & 46 & 46 & 14 \\
\hline 3 & $\begin{array}{lr}\text { Karyawan } & \text { dapat } \\
\text { memecahkan } & \text { masalah } \\
\text { pelanggan. } & \\
\end{array}$ & 32 & 32 & 51 & 51 & 12 \\
\hline 4 & $\begin{array}{lrr}\text { Karyawan cepat } & \text { tanggap } \\
\text { terhadap jasa } & \text { yang } \\
\text { dibutuhkan pelanggan. }\end{array}$ & 35 & 35 & 39 & 39 & \\
\hline 5 & $\begin{array}{l}\text { Karyawan memberitahukan } \\
\text { jadwal pelayanan. }\end{array}$ & 10 & 10 & 43 & 43 & \\
\hline 6 & $\begin{array}{l}\text { Karyawan memiliki } \\
\text { pengetahuan yang cukup }\end{array}$ & 23 & 23 & 61 & 61 & 12 \\
\hline 7 & $\begin{array}{lr}\text { Karyawan } & \text { mampu } \\
\text { memberikan rasa } & \text { aman } \\
\text { disetiap transaksi. } & \\
\end{array}$ & 41 & 41 & 46 & 46 & 9 \\
\hline 8 & Karyawan dapat di percaya. & 44 & 44 & 44 & 44 & 1 \\
\hline 9 & $\begin{array}{lr}\text { Karyawan peka dalam } \\
\text { mengetahui } \\
\text { pelanggan. }\end{array}$ & 25 & 25 & 40 & 40 & 30 \\
\hline 10 & $\begin{array}{l}\text { Karyawan mengetahui } \\
\text { kebutuhan khusus pelanggan }\end{array}$ & 15 & 15 & 42 & 42 & 3 \\
\hline 11 & $\begin{array}{l}\text { Karyawan memberikan } \\
\text { perhatian personal. }\end{array}$ & 12 & 12 & 31 & 31 & \\
\hline
\end{tabular}




\begin{tabular}{|l|l|l|l|l|l|l|l|l|l|l|l|l|}
\hline 10 & $\begin{array}{l}\text { Karyawan mengetahui } \\
\text { kebutuhan khusus pelanggan }\end{array}$ & 15 & 15 & 42 & 42 & 31 & 31 & 8 & 8 & 4 & 4 & 356 \\
\hline 11 & $\begin{array}{l}\text { Karyawan memberikan } \\
\text { perhatian personal. }\end{array}$ & 12 & 12 & 31 & 31 & 36 & 36 & 19 & 19 & 2 & 2 & 332 \\
\hline 12 & $\begin{array}{l}\text { Lengkapnya fasilitas fisik } \\
\text { yang dimiliki perusahaan. }\end{array}$ & 22 & 22 & 46 & 46 & 19 & 19 & 11 & 11 & 2 & 2 & 375 \\
\hline 13 & $\begin{array}{l}\text { Peralatan perusahaan yang } \\
\text { modern }\end{array}$ & 38 & 38 & 49 & 49 & 4 & 4 & 1 & 1 & 1 & 1 & 422 \\
\hline 14 & $\begin{array}{l}\text { Penampilan karyawan rapi } \\
\text { dan menarik. }\end{array}$ & 30 & 30 & 47 & 47 & 20 & 20 & 2 & 2 & 1 & 1 & 403 \\
\hline Jumlah & & & & & & & & & & & 5521 \\
\hline
\end{tabular}

Sumber: data primer yang diolah, 2017

Berdasarkan Tabel 7. Hasil Kuesioner Kualitas Pelayanan Jasa (X) diatas dapat dideskripsikan bahwa:

a) Pada pertanyaan pertama yaitu memberikan pelayanan sesuai janji, sebanyak 38 orang (38\%) menjawab sangat setuju, 49 orang (49\%) menjawab setuju, 11 orang (11\%) menjawab cukup setuju, 1 orang (1\%) menjawab tidak setuju dan 1 orang (1\%) menjawab sangat tidak setuju.

b) Pada pertanyaan kedua yaitu melakukan pelayanan yang tepat dan akurat, sebanyak 37 orang (37\%) menjawab sangat setuju, 46 orang (46\%) menjawab setuju, 14 orang (14\%) menjawab cukup setuju, dan 3 orang (3\%) menjawab tidak setuju.

c) Pada pertanyaan ketiga yaitu karyawan dapat memecahkan masalah pelanggan, sebanyak 32 orang (32\%) menjawab sangat setuju, 51 orang $(51 \%)$ menjawab setuju, 14 orang $(14 \%)$ menjawab cukup setuju, dan 3 orang (3\%) menjawab tidak setuju.

d) Pada pertanyaan keempat yaitu karyawan cepat tanggap terhadap jasa yang dibutuhkan pelanggan, sebanyak 35 orang $(35 \%)$ menjawab sangat setuju, 39 orang (39\%) menjawab setuju, 22 orang (22\%) menjawab cukup setuju, dan 4 orang (4\%) menjawab tidak setuju.

e) Padapertanyaan kelima yaitu karyawan memberitahukan jadwal pelayanan, sebanyak 10 orang (10\%) menjawab sangat setuju, 43 orang (43\%) menjawab setuju, 31 orang (31\%) menjawab cukup setuju, 10 orang (10\%) menjawab tidak setuju, dan 6 orang (6\%) menjawab sangat tidak setuju.

f) Pada pertanyaan keenam yaitu karyawan memiliki pengetahuan yang cukup, sebanyak 23 orang $(23 \%)$ menjawab sangat setuju, 61 orang (61\%) menjawab setuju, 12 orang (12\%) menjawab cukup setuju, 2 orang (2\%) menjawab tidak setuju, dan 2 orang (2\%) menjawab sangat tidak setuju. g) Pada pertanyaan ketujuh yaitu karyawan mampu memberikan rasa aman disetiap transaksi, sebanyak 41 orang $(41 \%)$ menjawab sangat setuju, 46 orang (46\%) menjawab setuju, 9 orang $(9 \%)$ menjawab cukup setuju, 3 orang (3\%) menjawab tidak setuju dan 1 orang (1\%) menjawab sangat tidak setuju.

h) Pada pertanyaan kedelapan yaitu karyawan dapat di percaya, sebanyak 44 orang $(44 \%)$ menjawab sangat setuju, 44 orang (44\%) menjawab setuju, 10 orang (10\%) menjawab cukup setuju, dan 2 orang (2\%) menjawab tidak setuju.

i) Pada pertanyaan kesembilan yaitu karyawan peka dalam mengetahui keinginan pelanggan, sebanyak 25 orang (25\%) menjawab sangat setuju, 40 orang $(40 \%)$ menjawab setuju, 30 orang (30\%) menjawab cukup setuju, 4 orang (4\%) menjawab tidak setuju dan i orang (1\%) menjawab sangat tidak setuju.

j) Pada pertanyaan kesepuluh yaitu karyawan mengetahui kebutuhan khusus pelanggan, sebanyak 15 orang $(15 \%)$ menjawab sangat setuju, 42 orang (42\%) menjawab setuju, 31 orang (31\%) menjawab cukup setuju, 8 orang (8\%) menjawab tidak setuju, dan 4 orang (4\%) menjawab sangat tidak setuju. k) Pada pertanyaan kesebelas yaitu karyawan memberikan perhatian personal, sebanyak 12 orang (12\%) menjawab sangat setuju, 31 orang (31\%) menjawab setuju, 36 orang $(36 \%)$ menjawab cukup setuju, 19 orang (19\%) menjawab tidak setuju, dan 2 orang (2\%) menjawab sangat tidak setuju. 1) Pada pertanyaan keduabelas lengkapnya fasilitas fisik yang dimiliki perusahaan, 22 orang (22\%) menjawab sangat stuju, 46 orang (46\%) menjawab setuju, 19 orang (19) menjawab cukup setuju, 11 orang (11\%) menjawab tidak setuju, dan 2 orang (2\%) menjawab sangat tidak setuju.

m) Pada pertanyaan ketiga belas yaitu peralatan perusahaan yang modern, sebanyak 38 orang (38\%) menjawab sangat setuju, 49 orang (49\%) menjawab 
setuju, 10 orang (10\%) menjawab cukup setuju, dan 3 orang $(3 \%)$ menjawab tidak setuju.

n) Pada pertanyaan keempat belas yaitu penampilan karyawan rapi dan menarik, sebanyak 30 orang (30\%) menjawab sangat setuju, 47 orang (47\%) menjawab setuju, 20 orang (20\%) menjawab cukup setuju, 2 orang ( $2 \%$ ) menjawab tidak setuju dan 1 orang (1\%) menjawab sangat tidak setuju.

Analisis deskripsi tentang kualitas pelayanan jasa $(\mathrm{X})$ dapat dilihat pada tabel di bawah ini:

\section{Tabeds \& Skr Tanggasan Responden Terbadap Kualitas Pelayanan Jasa 5521

$$
5521
$$$$
\frac{5521}{14 \times 5 \times 100} \times 100 \%
$$$$
=78,87 \%
$$

Sumber:dataprimer yang diolah 2017 rastas Skor Kualitas Pelayanan Jasa (X) di atas menunjukan bahwa kualitas pelayanan jasa PT. Pos Indonesia Cabang Pandan Sintang baik, hal ini terlihat dari tabel 7. skor tanggapan responden terhadap kualitas pelayanan jasa (X) sebesar
Maka dapat dihasilkan data peringkat kualitas pelayanan seperti yang dapat dilihat dalam tabel berikut ini:

Tabel 9. Kriteria Interpretasi Skor Kualitas Pelayanan Jasa (X)

\begin{tabular}{|c|c|}
\hline Interval tingkat intensitas & Kriteria \\
\hline $0 \%-20 \%$ & Sangat tidak baik \\
\hline $21 \%-40 \%$ & Tidak baik \\
\hline $41 \%-60 \%$ & Cukup baik \\
\hline $61 \%-80 \%$ & baik \\
\hline $81 \%-100 \%$ & Sangat baik \\
\hline
\end{tabular}

Sumber: data primer yang telah diolah, 2017

$78,87 \%$ dimana apabila kita lihat pada tabel 8 . kriteria interpretasi skor, berada diantara $61 \%$ $80 \%$ dengan kriteria baik. Hal ini membuktikan bahwa kualitas pelayanan jasa PT. Pos Indonesia Cabang Pandan Sintang adalah baik.

Tabel 10. Hasil Kuesioner Variabel Kepuasan Pelanggan (Y)

\begin{tabular}{|c|c|c|c|c|c|c|c|c|c|c|c|c|}
\hline \multirow{2}{*}{ No } & \multirow{2}{*}{ Item pertanyaan } & \multicolumn{2}{|l|}{ SS } & \multicolumn{2}{|l|}{$\mathbf{S}$} & \multicolumn{2}{|c|}{ CS } & \multicolumn{2}{|c|}{ TS } & \multicolumn{2}{|c|}{ STS } & \multirow{2}{*}{ skor } \\
\hline & & $\mathbf{F}$ & $\%$ & $\mathbf{F}$ & $\%$ & $\mathbf{F}$ & $\%$ & $\mathbf{F}$ & $\%$ & $\mathbf{F}$ & $\%$ & \\
\hline 1 & $\begin{array}{ll}\begin{array}{l}\text { Produk yang } \\
\text { memenuhi }\end{array} & \begin{array}{r}\text { ditawarkan } \\
\text { kebutuhan }\end{array} \\
\text { pelanggan. } & \\
\end{array}$ & 45 & 45 & 49 & 49 & 4 & 4 & 1 & 1 & 1 & 1 & 436 \\
\hline 2 & $\begin{array}{llr}\text { Kualitas } & \text { pelayanan yang } \\
\text { dilakukan } & \text { telah memberikan } \\
\text { kepuasan. } & & \end{array}$ & 50 & 50 & 39 & 39 & 11 & 11 & 0 & 0 & 0 & 0 & 439 \\
\hline 3 & $\begin{array}{l}\text { Tidak ada komplain atau } \\
\text { keluhan terhadap pelayanan } \\
\text { kantor pos. }\end{array}$ & 32 & 32 & 29 & 29 & 32 & 32 & 6 & 6 & 1 & 1 & 385 \\
\hline 4 & $\begin{array}{l}\text { Pelanggan memberikan pujian } \\
\text { setelah melakukan transaksi di } \\
\text { kantor pos. }\end{array}$ & 10 & 10 & 42 & 42 & 39 & 39 & 8 & 8 & 1 & 1 & 352 \\
\hline 5 & $\begin{array}{l}\text { Melakukan transaksi di kantor } \\
\text { pos merupakan sebuah } \\
\text { pengalaman yang bagus. }\end{array}$ & 26 & 26 & 41 & 41 & 29 & 29 & 3 & 3 & 1 & 1 & 388 \\
\hline Jum & & & & & & & & & & & & 2000 \\
\hline
\end{tabular}

Sumber: data primer yang telah diolah, 2017

Berdasarkan Tabel 10. Hasil Kuesioner Variabel Kepuasan Pelanggan (Y) diatas dapatdideskripsikan bahwa: a) Pada pertanyaan pertama yaitu produk yang ditawarkan memenuhi kebutuhan pelanggan, sebanyak 45 orang (45\%) menjawab sangat setuju, 
49 orang $(49 \%)$ menjawab setuju, 4 orang $(4 \%)$ menjawab cukup setuju, 1 orang (1\%) menjawab tidak setuju dan 1 orang (1\%) menjawab sangat tidak setuju.

b) Pada pertanyaan kedua yaitu kualitas pelayanan yang dilakukan telah memberikan kepuasan, sebanyak 50 orang (50\%) menjawab sangat setuju, 39 orang $(39 \%)$ menjawab setuju, dan 11 orang (11\%) menjawab cukup setuju.

c) Pada pertanyaan ketiga yaitu tidak ada komplain atau keluhan terhadap pelayanan kantor pos, sebanyak 32 orang (32\%) menjawab sangat setuju, 29 orang (29\%) menjawab setuju, 32 orang (32\%) menjawab cukup setuju, 6 orang $(6 \%)$ menjawab tidak setuju dan 1 orang (1\%) menjawab sangat tidak setuju.

d) Pada pertanyaan keempat yaitu pelanggan memberikan pujian setelah melakukan transaksi di kantor pos, sebanyak 10 orang (10\%) menjawab sangat setuju, 42 orang (42\%) menjawab setuju, 39 orang $(39 \%)$ menjawab cukup setuju, 8 orang (8\%) menjawab tidak setuju, dan 1 orang $(1 \%)$ menjawab sangat tidak setuju.

e) Pada pertanyaan kelima yaitu melakukan transaksi di kantor pos merupakan sebuah pengalaman yang bagus, sebanyak 26 orang (26\%) menjawab sangat setuju, 41 orang $(41 \%)$ menjawab setuju, 29 orang (29\%) menjawab cukup setuju, 3

Berdasarkan tabel 12. Kriteria Interpretasi Skor Kepuasan Pelanggan di atas menunjukan bahwa kepuasan pelanggan PT. Pos Indonesia Cabang Pandan Sintang baik, hal ini terlihat dari tabel 11. skor tanggapan responden terhadap kepuasan pelanggan (Y) sebesar $80 \%$ dimana apabila kita lihat pada tabel 12 . kriteria interpretasi skor, berada diantara $61 \%$ - 80\% dengan kriteria puas. Hal ini membuktikan bahwa kepuasan pelanggan PT. Pos Indonesia Cabang Pandan Sintang adalah puas. orang $(3 \%)$ menjawab tidak setuju dan 1 orang (1\%) menjawab sangat tidak setuju.

Analisis deskripsi tentang kepuasan pelanggan (Y) dapat dilihat pada tabel di bawah ini:

Tabel 11. Skor Tanggapan Responden Terhadap Kepuasan Pelanggan (Y)

\begin{tabular}{|c|c|}
\hline Skor Total & Skor dalam persen (\%) \\
\hline 2000 & $\frac{2000}{5 \times 5 \times 100} \times 100 \%=80 \%$ \\
\hline
\end{tabular}

Sumber: data primer yang diolah, 2017

Maka dapat dihasilkan data peringkat kepuasan pelanggan seperti yang dapatdilihat dalam tabel berikut ini:

Tabel 12. Kriteria Interpretasi Skor Kepuasan Pelanggan (Y)

\begin{tabular}{|c|c|}
\hline Interval tingkat intensitas & Kriteria \\
\hline $0 \%-20 \%$ & Sangat tidak puas \\
\hline $21 \%-40 \%$ & Tidak puas \\
\hline $41 \%-60 \%$ & Cukup puas \\
\hline $61 \%-80 \%$ & Puas \\
\hline $81 \%-100 \%$ & Sangat puas \\
\hline
\end{tabular}

Sumber: data diolah, 2017

Pengujian Hipotesis

a. Analisis Regresi Sederhana

Kegunaan regresi dalam penelitian salah satunya adalah untuk meramalkan atau memprediksi variabel terikat (Y) apabila variabel bebas $(\mathrm{X})$ diketahui. Adapun hasil analisis regresi sederhana yang diolah menggunakan program SPSS 21 For Windows adalah sebagai berikut:

Tabel 13. Hasil Analisis Regresi Sederhana

Coefficients $^{a}$

\begin{tabular}{|c|c|c|c|c|c|c|}
\hline \multirow[b]{2}{*}{ Mode } & & \multicolumn{2}{|c|}{ Unstandardized Coefficients } & \multirow{2}{*}{$\begin{array}{c}\begin{array}{c}\text { Standardized } \\
\text { Coefficients }\end{array} \\
\text { Beta } \\
\end{array}$} & \multirow[b]{2}{*}{$t$} & \multirow[b]{2}{*}{ Sig. } \\
\hline & & $B$ & Std. Error & & & \\
\hline \multirow[t]{2}{*}{1} & (Constant) & 3,674 & 1,530 & & 2,401 &, 018 \\
\hline & Kualitas Pelayanan Jasa &, 296 &, 027 &, 736 & 10,762 &, 000 \\
\hline
\end{tabular}

a. Dependent Variable: Kepuasan Pelanggan

Sumber: data primer yang diolah dengan program SPPS 21 For Window 
Dari hasil uji Tabel 13. Hasil Analisis Regresi Sederhana yang diolah menggunakan SPSS 21 For Window di atas dapat disimpulkan bahwa (a) = 3,674 dan beta $=0,736$, maka diperoleh persamaan perhitunganya $\mathrm{v}=3,674+0,736 \mathrm{X}$. Koefisien regresi 0,736 menyatakan bahwa setiap peningkatan $1 \%$ variabel kualitas pelayanan jasa (X) maka kepuasan pelanggan (Y) akan meningkatkan sebesar 0,736 . b. Analisis Korelasi Spearman Rank Untuk mengetahui tingkat hubungan (korelasi) bila datanya berbentuk ordinal maka digunakan teknik statistik Korelasi Spearman Rank. Ada pun hasil analisis Korelasi Spearman Rank yang diolah menggunakan program SPSS 21 For Windows adalah sebagai berikut:

Tabel 14. Nilai Korelasi Rank Spearman

Correlations

\begin{tabular}{|c|c|c|c|c|}
\hline & & & $\begin{array}{c}\text { kualitas } \\
\text { pelayanan } \\
\text { jasa }\end{array}$ & $\begin{array}{l}\text { kepuasan } \\
\text { pelanggan }\end{array}$ \\
\hline \multirow[t]{6}{*}{ Spearman's rho } & \multirow[t]{3}{*}{ kualitas pelayanan jasa } & Correlation Coefficient & 1,000 &, $727^{\mathrm{N}}$ \\
\hline & & Sig. (2-tailed) & &, 000 \\
\hline & & N & 100 & 100 \\
\hline & \multirow[t]{3}{*}{ kepuasan pelanggan } & Correlation Coefficient &, $727^{\star \star}$ & 1,000 \\
\hline & & Sig. (2-tailed) &, 000 & \\
\hline & & $N$ & 100 & 100 \\
\hline
\end{tabular}

**. Correlation is significant at the 0.01 level (2-tailed).

Sumber: data primer yang diolah dengan program SPPS 21 For Window

Berdasarkan Tabel 14. Nilai Korelasi Rank Spearman diatas yang diolah menggunakan SPSS 21 For windows menunjukan bahwa output kualitas pelayanan jasa dengan kepuasan pelanggan menghasilkan angka 0,727. Berdasarkan kriteria, angka tersebut bermakna bahwa hubungan variabel kualitas pelayanan jasa dan kepuasan pelanggan kuat. Hal ini di perjelas dengan melihat tabel dibawah ini:

Tabel 15. Tabel Untuk Memberikan Interpretasi Koefisien Korelasi

\begin{tabular}{|c|c|}
\hline Interval Koefisien & Tingkat Hubungan \\
\hline $0,00-0,199$ & Sangat rendah \\
$0,20-0,399$ & Rendah \\
$0,40-0,599$ & Sedang \\
$0,60-0,799$ & Kuat \\
$0,80-1,000$ & Sangat kuat \\
\hline
\end{tabular}

Sumber : Sugiyono (2015:184)

\section{c. Uji hipotesis}

Dalam penelitian ini, dilakukan uji hipotesis untuk mengetahui ada tidaknya pengaruh kualitas pelayanan jasa sebagai variabel bebas terhadap kepuasan pelanggan sebagai variabel terikat. Langkah-langkah melakukan uji hipotesis adalah sebagai berikut:

\section{a. Hipotesis}

Ho: Tidak terdapat pengaruh yang signifikan antara kualitas pelayanan jasa terhadap kepuasan pelanggan pada PT. Pos Indonesia cabang Pandan Sintang.

Ha: Terdapat pengaruh yang signifikan antara kualitas pelayanan jasa terhadap kepuasan pelanggan pada PT. Pos Indonesia cabang Pandan Sintang.

b. Menentukan $t_{\text {hitung }}$

hasil uji $\mathrm{t}_{\text {hitung }}$ dalam penelitian ini adalah sebagai berikut:

$+\ldots-n \frac{\sqrt{n-2}}{t_{\text {hitung }}}=0,727 \sqrt{\frac{100-2}{1-0,727^{2}}}$
$t_{\text {hitung }}=10,481$

c. Menentukan $\mathrm{t}_{\text {tabel }}$

Untuk menghitung $t_{\text {tabel }}$ digunakan rumus interpolasi berikut:

$$
t_{\text {tabel }}=t_{0}+\frac{t_{1}-t_{0}}{B_{1}-B_{0}} x\left(B-B_{0}\right)
$$


Dimana:

$\mathrm{t}_{0} \quad=$ nilai $\mathrm{t}_{\text {tabel }}$ pada awal nilai yang sudah ada

$\mathrm{t}_{1} \quad=$ nilai $\mathrm{t}_{\text {tabel }}$ pada akhir nilai yang sudah ada $(1,980)$

$\mathrm{B}=$ nilai $\mathrm{dk}$ yang dicari (98)

$\mathrm{B}_{0} \quad=$ nilai $\mathrm{dk}$ pada awal nilai yang sudah ada (60)

$\mathrm{B}_{1} \quad=$ nilai dk pada akhir nilai yang sudah ada. (120)

$$
\begin{aligned}
\mathrm{dk} & =\mathrm{n}-2 \\
& =100-2 \\
& =98
\end{aligned}
$$

$t_{\text {tabel }}=2,000+\frac{1,980-2,000}{120-6 n} x(98-60)$

$t_{\text {tabel }}=2,000+\frac{-0,02}{60} x(38)$

d. Kriteria pengujian

Bila $\mathrm{t}_{\text {hitung }}<\mathrm{t}_{\text {tabel }}$ maka Ho diterima dan Ha ditolak.

Bila $t_{\text {hitung }}>t_{\text {tabel }}$ maka Ho ditolak dan Ha diterima.

e. Membandingkan $t_{\text {hitung }}$ dengan $t_{\text {tabel }}$

Nilai $t_{\text {hitung }}>t_{\text {tabel }}(10,481>1,9873)$

\section{f. Membuat kesimpulan}

Berdasarkan kriteria pengujian maka dapat disimpulkan bahwa $t_{\text {hitung }}(10,481)>t_{\text {tabel }}(1,9873)$ maka Ho ditolak dan Ha diterima, yang peneliti gambarkan pada gambar berikut:

Gambar 4.1. Uji Hipotesis Dua Pihak

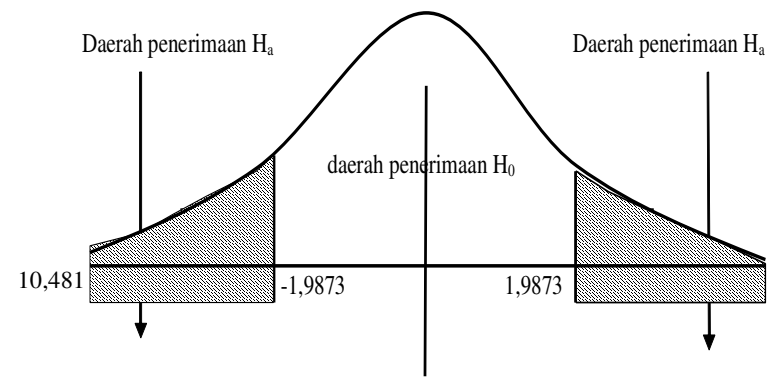

Dari gambar 4.1. uji hipotesis dua pihak diatas, dapat dilihat bahwa $\mathrm{t}_{\text {hitung }}$ jatuh didaerah penolakan $\mathrm{H}_{0}$, ini berarti $\mathrm{H}_{1}$ diterima.sehingga dapat dikatakan bahwa benar adanya pengaruh yang signifikan kualitas pelayanan jasa terhadap kepuasan pelanggan pada PT. Pos Indonesia Cabang Pandan Sintang. g. Uji Koefisien Determinasi $\left(\mathrm{R}^{2}\right)$

Koefisien determinasi $\left(\mathrm{R}^{2}\right)$ digunakan untuk mengetahui tingkat yang paling baik antara dua variabel atau digunakan untuk mengukur besarnya konstribusi dari variabel Kualitas Pelayanan Jasa (X) terhadap variasi naik turunnya variabel Kepuasan Pelanggan (Y) yang biasnya dinyatakan dalam persentase. Adapun hasil uji koefisien determinasi adalah sebagai berikut:

Dari uji koefisien determinasi $\left(\mathrm{R}^{2}\right)$ diatas, dapat disimpulkan bahwa pengaruh kualitas pelayanan jasa terhadap kepuasan pelanggan pada PT. Pos Indonesia Cabang Pandan Sintang sebesar $58,8529 \%$ sedangkan sisanya sebesar $41,1471 \%$ di pengaruhi oleh faktor lain yang tidak penulis teliti. Nilai 58,8529\% menunjukan bahwa pengaruh kualitas pelayanan jasa positif dan signifikan terhadap kepuasan pelanggan pada PT Pos Indonesia Cabang Pandan Sintang

\section{Kesimpulan}

Berdasarkan penelitian yang dibahas pada bab sebelumnya, maka dapat di tarik beberapa kesimpulan sebagai berikut:

1.Tanggapan responden terhadap kualitas pelayanan jasa yang diukur dengan 14 pertanyaan terhadap 100 responden pada PT. Pos Indonesia dikatakan baik yakni sebesar $78,87 \%$, hal ini diperjelas dengan melihat tabel interpretasi skor kualitas pelayanan jasa yang berada di rentang $61 \%$ - 80\% dengan kriteria baik. Tanggapan responden terhadap kepuasan pelanggan yang diukur dengan 5 pertanyaan terhadap 100 responden pada PT. Pos Indonesia Cabang Pandan Sintang dikatakan puas dengan persentase skor total $80 \%$, hal ini juga diperjelas dengan melihat tabel interpretasi skor kepuasan pelanggan yang berada direntang $61 \%$ $80 \%$ dengan kriteria puas.

2. Besarnya hubungan antara kualitas pelayanan jasa dengan kepuasan pelanggan pada PT. Pos Indonesia Cabang Pandan Sintang yang dihitung menggunakan Korelasi Spearman Rank yaitu sebesar 0,727 dengan tingkat hubungan kuat.

3. Berdasarkan uji hipotesis bahwa $t_{\text {hitung }}(10,481)$ $>t_{\text {tabel }}(1,9873)$ maka dapat dikatakan bahwa benar adanya pengaruh yang signifikan kualitas pelayanan jasa terhadap kepuasan pelanggan pada PT. Pos Indonesia Cabang Pandan Sintang.

4. Besarnya pengaruh kualitas pelayanan jasa terhadap kepuasan pelanggan pada PT. Pos Indonesia Cabang Pandan Sintang yaitu sebesar $58,8529 \%$ sedangkan sisanya sebesar $41,1471 \%$ di pengaruhi oleh faktor lain yang tidak penulis teliti. 


\section{Saran}

Berdasarkan hasil penelitian, maka peneliti memberi saran atau rekomendasi dalam perbaikan kedepan seperti berikut:

1. Sebaiknya PT. Pos Indonesia Cabang Pandan Sintang yang memiliki citra baik harus terus meningkatkan kualitas pelayanan jasa yang meliputi reliabilitas (reliability), daya tanggap (responsiveness), jaminan (assurance), empati (emphaty), dan bukti fisik (tangibles) guna meningkatkan kepuasan pelanggan kearah yang lebih baik lagi.

2.Sebaiknya perusahaan berusaha mempertahankan kinerjanya dan senantiasa memperhatikan atribut yang memengaruhi kepuasan pelanggan agar tercipta kesesuaian antara persepsi dan harapan pelanggan.

3. Sebaiknya PT. Pos Indonesia Cabang Pandan Sintang memperhatikan faktor lainya di luar kualitas pelayanan jasa yang berdasarkan hasil penelitian cukup berpengaruh sehingga kebutuhan pelanggan semakin terpenuhi.

\section{DAFTAR PUSTAKA}

Arikunto, S. (2010). Prosedur Penelitian Suatu Pendekatan Praktik. Jakarta: Rineka Cipta

Budikho. 2016. Delapan dimensi kualitas produk. Diakses dari http://www.google.co.id/ m?\&q=8+kualitas+layanan+menurut + garvin [18 Januari 2017]

Burhanuddin, M. 2012. Dimensi Kualitas Jasa. Diakses dari http:// alvinburhani.wordpress.com/2012/04/13/ $\mathrm{d} \mathrm{i} \mathrm{mens} \mathrm{i-k} \mathrm{u} \mathrm{a} \mathrm{li} \mathrm{t} \mathrm{a} \mathrm{s} \mathrm{-} \mathrm{jas} \mathrm{a} /$ ? e pi $=7 \% 2 \mathrm{C} 2776218087$ [ 28 Oktober 2016]

Devianti. 2014. Devinisi kualitas menurut Goetsch dan davis. Diakses darihttp:// deviantipscjumat.blogspot.com/2014/04/ devinisi-kualitas-menurut goetschdan.html[18 Januari 2017]

Hadiyati, E. Analisis kualitas pelayanan dan pengaruhnya terhadap loyalitas pelanggan.
Jurnal Universitas Gajayana Malang. Volume 2 nomor 2, hlm 81-90

Hermansyah. 2014. Pengaruh citra merk zuzuki new satria ful50 terhadap keputusan konsumen. Jurnal ilmu sosial dan politik. Jilid 14 Nomor 2, hlm 219-228

Irianto, A. 2004. Statistik Konsep Dasar Aplikasi dan Pengembangannya. Jakarta: Prenadamedia Group

Musanto, T. 2004. Faktor-faktor kepuasan pelanggan dan loyalitas pelanggan studi kasus pada CV. Sarana Media Advertising Surabaya. Jurnal ekonomi manajemen. Volume 6 nomor 2

Riduwan dan Sunarto. Pengantar Statistika untuk penelitian Pendidikan, Sosial, Ekonomi, Komunikasi dan Bisnis. Bandung: Alfabeta

Sugiyono. 2015. Metode Penelitian Kuantitatif Kualitatif dan R\&D.Bandung: Alfabeta

Sugiyono. 2004. Metode Penelitian Bisnis. Bandung: Alfabeta

Thohuri, R. 2011. Manajemen Pemasaran Jasa. Diakses dari http://thohuri.blogspot.in/p/ manajemen-pemasaran-jasa.html [28 Oktober 2016]

Tjiptono, F dan Chandra, G. 2016. Service Quality dan Satisfaction. Yogyakarta: Andi

Tjiptono, F. 2005. Pemasaran jasa. Malang: Banyumedia

Widjoyo, I.O, Rumambi, L.J dan Kunto. 2013. Analisa kualitas layanan terhadap kepuasan konsumen pada layanan Drive Thru McDonald's Basuki Rahmat di Surabaya. Jurnal manajemen pemasaran. Volume 1 nomor 1, hlm1-12

Ghazali, R.M. 2010. Analisis Pengaruh Lokasi, Dan Kualitas Layanan Terhadap Keputusan Membeli. Semarang: Universitas Diponegoro 